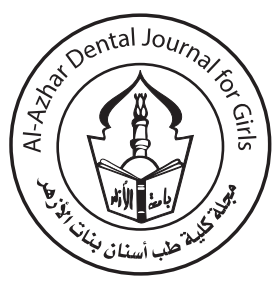

\title{
Maxillary Tissue Changes under Complete Dentures Opposing Two Different Mandibular Implant Support Overdentures
}

\author{
Amany Abdel-Fattah ${ }^{(1)}$, Mostafa Abdel-Ghany ${ }^{(2)}$, Nesrin El-Mahrouky ${ }^{(3)}$, Yasmeen Al-Mahdy ${ }^{(4)}$ \\ and Shadia El-Sayed ${ }^{(5)}$
}

Codex : 09/1801

azhardentj@azhar.edu.eg

http://adjg.journals.ekb.eg

\section{KEYWORDS}

Dental implant,

overdenture,

single implant,

maxillary bone change,

mucosa thickness

\begin{abstract}
Aim: The aim of the study was to study the maxillary tissue changes under complete dentures opposing mandibular implant-supported overdenture retained by either two or single midline implant. Material and Methods: Fourteen completely edentulous patients were chosen for this study. Patients were randomly divided into two groups: Group I; Seven patients received mandibular overdenture retained with 2 implants in the canine region bilaterally with ball and socket attachment. Group II; Seven patients received mandibular overdenture retained with single implant in the midline with ball and socket attachment. Clinical and radiographic evaluations were done by measuring the thickness of the soft tissue overlying the anterior maxillary ridge and amount of bone resorption respectively, measured at 2 points $1 \mathrm{~cm}$ and $2 \mathrm{~cm}$ bilaterally to the midline at time of implant loading, 3, 6, 9 and at 12 months. Results: there was non-significant increase in maxillary mucosa thickness in both groups at both points of measurements. Also, there were posterior radiographic bony changes in maxillary ridge within both groups. There was significant increase in maxillary bony changes in Group II in comparison to Group I. Conclusion: Within the limitations of this study, it was concluded that there was slight increase in the soft tissue thickness overlying the anterior maxillary ridge in each group. But there was slight increase in Group II more than Group I. More bone resorption in posterior region of maxilla was observed in Group II patients.
\end{abstract}

\section{INTRODUCTION}

Mandibular implant overdentures became a well-proven and successful treatment option for the edentulous patients with long-term predictable outcomes, using conventional loading protocols ${ }^{(1)}$. Thus treating edentulous patients with implant retained overdentures are able

1. Dentist at Ministry of Health

2. Professor of Removable Prosthodontics and Dean of Faculty of Dental Medicine for Girls, Al-Azhar University

3. Professor of Removable Prosthodontics, Faculty of Dental Medicine for Girls, Al-Azhar University.

4. Assistant Professor of Removable Prosthodontics, Faculty of Dental Medicine for Girls, Al-Azhar University

5. Assistant Professor of Oral and Maxillofacial Surgery, Faculty of Dental Medicine for Girls, , Al-Azhar University 
to increase retention and stability and to reduce pain and discomfort ${ }^{(2,3)}$.

Two-implant supported mandibular overdentures were proved as efficient in supporting edentulous mandible ${ }^{(4)}$.

It was found that the anterior part of the maxilla is the weakest part of the upper arch to resist stress, Thus when lower anterior teeth occlude anterior to the basal support or when using implants in the edentulous mandible, trauma is inevitable ${ }^{(5,6)}$. In situations in which mandibular implant supported overdentures oppose maxillary complete dentures, a condition may be produced at the prosthesistissue interface that are similar to those observed when mandibular distal extension removable partial denture opposes maxillary complete denture in which mandibular posterior prosthesis support is lost ${ }^{(7)}$. Many authors claimed that a similar set of biomechanical relationships which occur with combination syndrome studied by Kelly may exist when mandibular implants are substituted for the natural anterior teeth in a sample of edentulous patients restored with implant. The use of mucosa supported mandibular complete over denture may reduce the amount of alveolar ridge resorption of the antagonistic maxillary arch. The mainly mucosasupported implant overdenture is that which retained via magnet or ball attachments on two implants ${ }^{(5}$, ${ }^{8-12)}$. In addition to that, Bone loss from the anterior part of the maxillary jaw is the key to other changes. With the anterior loss of bone, a flabby hyperplastic tissue makes up the anterior part of the ridge which does not support the denture base and it folds forward forming a crease. As the bone and ridge height decrease anteriorly, the posterior residual ridge becomes larger with down-growth of the tuberosities ${ }^{(11,5)}$.

An alternative approach is a mandibular overdenture supported by a single midline implant to oppose a complete maxillary denture. It was claimed that oral rehabilitation using single midline implant is an economical therapeutic alternative to conventional mandibular complete dentures especially for older patients whose chief complaints are related to discomfort, instability and lack of retention of a mandibular complete denture. Another advantage of the median position is that the symphysis constitutes an excellent host site for an implant in terms of bone quantity and quality ${ }^{(13)}$.

The aim of the study was to assess the maxillary tissue changes under complete dentures opposing two different mandibular implant supported overdentures.

\section{MATERIAL AND METHODS}

Fourteen completely edentulous patients were selected from the outpatient clinic of Removable Prosthodontic Department, Faculty of Dental Medicine for Girls, Al-Azhar University. Patients were selected according to inclusion criteria:

1. Patients were free from any debilitating diseases that contraindicate implant surgery.

2. Patients' ages ranged between 45-50 years and were all non-smokers.

3. Mandibular ridge had adequate width, height and contour which covered with firm and healthy mucosa that was of normal color, condition and thickness and free of any sign of inflammation or ulceration.

4. All patients were free from TMJ neuromuscular problems and had normal maxillo-mandibular relationship (Angle class I) with sufficient interarch space.

All patients were subjected to a session of education regarding implant importance, need, advantage, maintenance and care. A signed consent was drawn from each patient for agreement and approval of treatment plan.

Accurate extraoral and intraoral visual and digital examinations were done. Also, size and shape of the arches and alveolar ridges were evaluated both clinically and by Digital Ortho-Pantogram 
(OPG). Ridge mapping was done to evaluate the buccolingual width of the ridge at the prospective implant site by using a standardized sharpened osteometer under local anesthesia. Bone height, quality and quantity of the bone was measured and the dimensions of the implants were selected. Implant length and diameter was predetermined before surgical procedure. All patients received implant with the same length $(11 \mathrm{~mm})$ and diameter $(3.4 \mathrm{~mm})$.

Patients were divided into two groups according to number of mandibular implants; each group included 7 patients as follows:

Group I: patients received mandibular overdenture retained with 2 implants in the canine region bilaterally with ball and socket attachment.

Group II: patients received mandibular overdenture retained with single implant in the midline with ball and socket attachment.

\section{Surgical and Prosthetic procedures:}

New conventional maxillary and mandibular complete dentures were constructed. The maxillary and mandibular teeth were set up according to the mechanical and aesthetic requirements in balanced articulation using anatomical cross-linked acrylic teeth. All laboratory procedures were completed conventionally.

Duplicate of patient's lower complete denture was made of transparent acrylic resin. Standardized metal marking balls ( $3 \mathrm{~mm}$ in diameter) were sunk into holes at the anticipated implant region in each group.

All patients were subjected to digital panoramic radiograph with the stent in place showing the position of the balls and identifying the sites of anticipated implant positions. Tracing of the panoramic radiographs was done to measure bone length in the radiograph. The lengths of the implants were determined in the anticipated implant sites (Fig.1). The radiographic stent was then converted to a surgical stent by removing the metallic balls and circular holes were made in the site of implant placement.

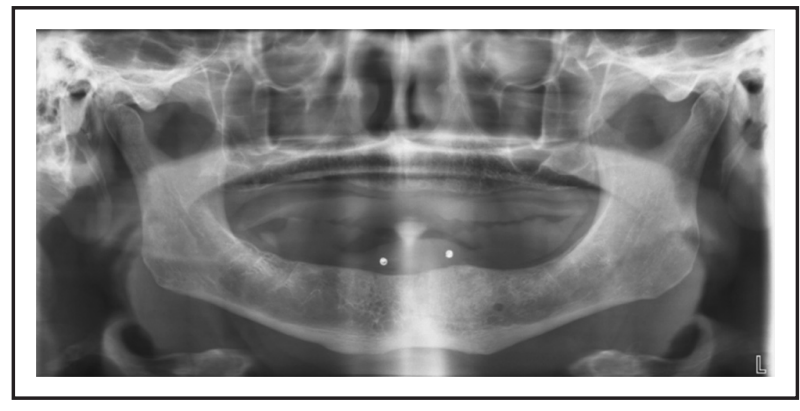

Fig. (1) Preoperative digital orthopantogram with radiographic stent in place.

The surgical procedure was carried out two to four weeks after denture insertion. Medication started one hour prior to surgical procedure and continued for five days after surgery. Prophylactic antibiotic Analgesic, anti-inflammatory and antiseptic mouth wash were administrated to all patients.

A flapless surgical technique was made under local anesthesia. The surgical stent was seated on ridge to ensure appropriate positioning of the osteotomy sites which was prepared in the mandible either in the canine region bilaterally or at the midline (in group I and II respectively).

All patients received root form implant screw design 3.4 x $11 \mathrm{~mm}$ (TUT dental implant, Egyptian company for dental implants (ECDI), Egypt). The implant was inserted till the implant shoulder was flushed with the bone margin. Protective cover screws were screwed to the implants allowing the site to heal and osseointegration to occur.

Post-operative instructions regarding oral hygiene, maintenance and soft diet for two weeks were given. All patients were instructed not to use their dentures for two weeks to avoid loading on the implant. The existing mandibular dentures were relieved in their fitting surface opposing the implants' positions to avoid direct contact between denture acrylic base and implants to allow enough room for the application of the soft tissue conditioning material.

Mucosal healing was reviewed after one week of surgery and regular recall appointments of patients 
were scheduled. A healing period of three months was allowed to assure complete osseointegration of the implants.

Second stage surgery was performed under local anesthesia after three months of implant placement after making digital OPG for inspection of implant osseointegration (Fig.2a,b). The implant site was detected using the surgical template. Tissue punch was made over the site of the implant fixture, covering screws were removed and ball attachments were threaded to the fixtures. The length of the attachment was chosen to reach about $2 \mathrm{~mm}$ supragingivally after healing. Testing of implant stability was done by percussion on the top of implant by mirror handle to hear resonant sound. Successful osseointegration presented no mobility.

Metal sockets were snapped into the ball abutments intraorally. Relief was created in the fitting surface of the overdenture to give room and no interference opposite to the sockets bilaterally or in the midline in group I and group II respectively. Then, metal sockets were picked up intraorally to the fitting surface of mandibular denture with autopolymerized acrylic resin.

Patients were instructed to be on a regular recall schedule to monitor Maxillary soft tissue and bone changes and for maintenance.

\section{Clinical Evaluation}

The thickness of the soft tissue overlying the anterior maxillary ridge was measured at 2 points bilaterally; $1 \mathrm{~cm}$ and $2 \mathrm{~cm}$ lateral to the midline by using a sharp probe with rubber stopper (Fig.3). The measurements were added and the means were calculated and analyzed immediately after loading of the implant and then through follow up at 3, 6, 9 and 12 months to evaluate the effect of two designs of mandibular implant-supported overdentures on the mucosa of antagonistic maxillary bony ridge under complete conventional denture.

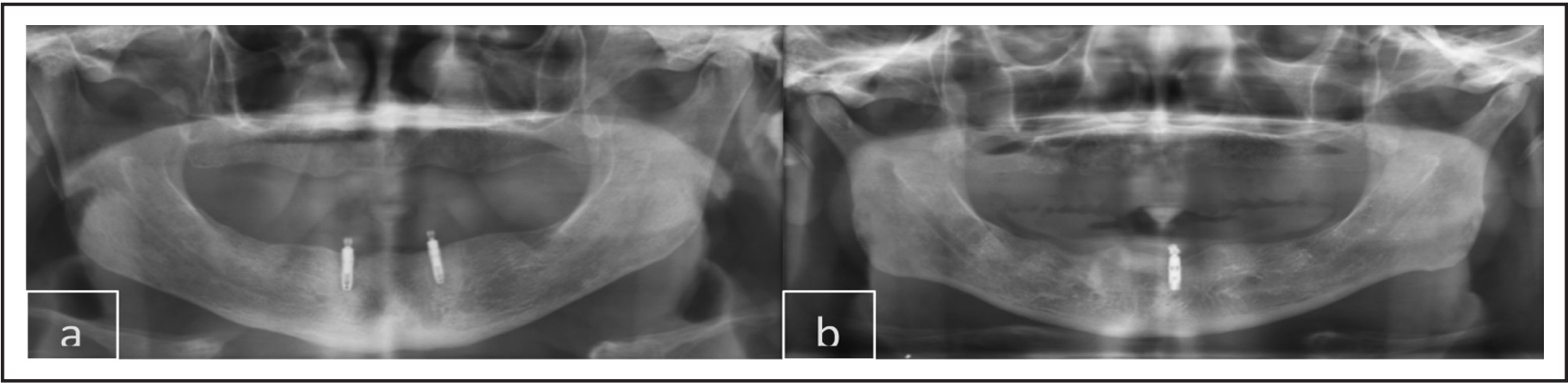

Fig. (2) a,b: Post-operative Panorama of group I and group II respectively after 3 months of implant insertion.

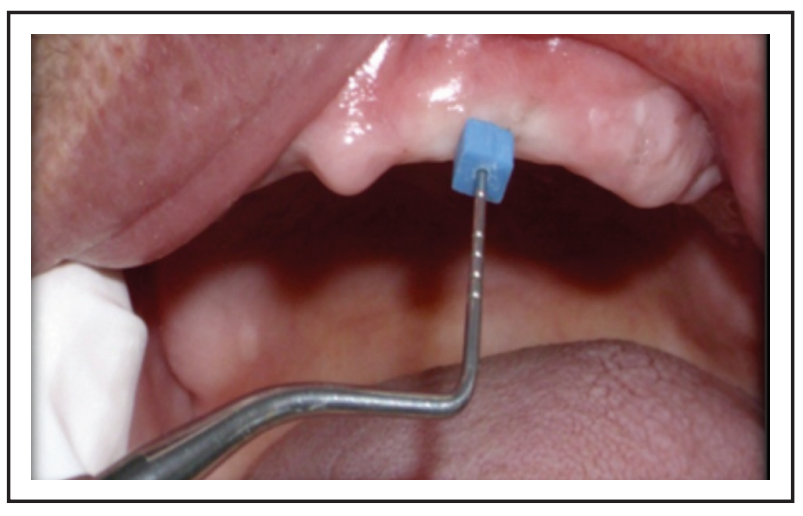

Fig. (3) Measurement of thickness of soft tissue overlying the anterior maxillary ridge using a probe with rubber stopper.

\section{Radiographic Evaluation}

Digital OPG was taken to measure the amount of maxillary ridge resorption. For each patient, Standardized Digital OPG were done after implant loading and at 3,6,9 and 12 months afterwards using the same machine, the same position of the patient and the automatic processor for standardization of contrast of the radiographs. Two anatomical points considered; the anterior nasal spine and the lowest midline point on the anterior maxillary 
ridge. The distance between them was measured. Two investigators examined all tracings twice and separately. A line was drawn joining the inferior margins of the images of the zygomatic processes of the maxillae bilaterally (LZ). A second line was drawn joining the inferior points of the borders of the bony orbits (LO). On both sides, a line perpendicular to the interorbital line from the point where it intersected the inferior border of the orbit was drawn. This perpendicular line was extended to the height of the alveolar crest in the first molar region. ${ }^{(14-16)}$

The midline was determined by a line connecting a point representing the anterior nasal spine and a point representing the lowest midline point on the anterior maxillary ridge. On both sides, at the midline from a point representing the middle of the triangle $a b c$ was drawn and extended to the tracing of the height of the alveolar crest. $X$ is the distance from interorbital line to zygomatic process (X1 from right side and $\mathrm{X} 2$ from left side); $Y$ is the distance from zygomatic process line to alveolar crest (posterior region) ( $\mathrm{Y} 1$ from right side and $Y 2$ from left side); and $Z$ is the distance from the zygomatic process line to alveolar crest (anterior region) $\mathrm{Z} 1$ from right side and $\mathrm{Z} 2$ from the left side). All measurements were made to the nearest $0.2 \mathrm{~mm}$ by using a dialcaliper.

The mean of the ratios $X / Y$ and $X / Z$ were calculated to nearest $0.01 \mathrm{~mm}$. The use of ratios measurement was done to overcome errors in patient's position on panoramic machine. All digital OPG of the patients were analyzed. Tracing and measurements were done using DBSWIN-5.1.0Build-8119 Software program (Fig.4 and 5).

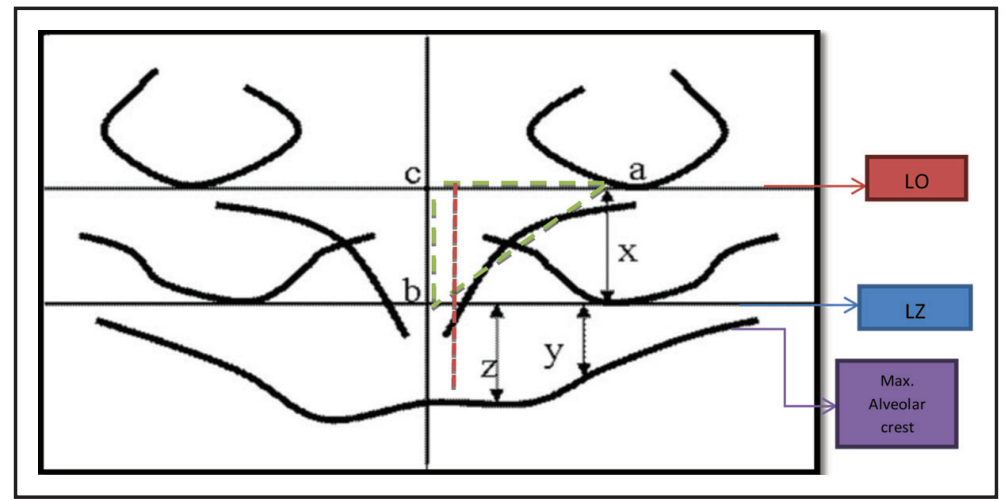

Fig. (4) Diagram of Lines and points of Panorama tracing.

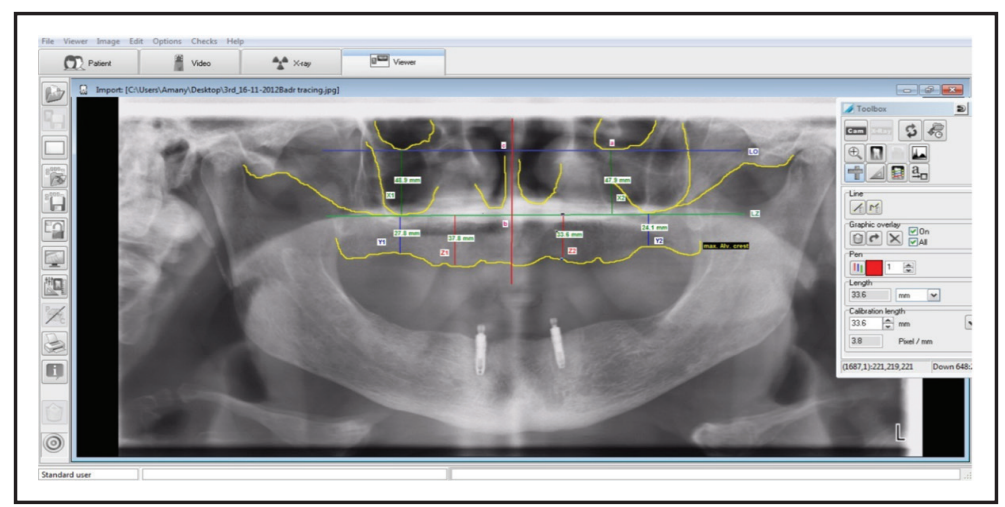

Fig. (5) Digital panorama analyzed by DBSWIN-5.1.0-Build-8119 Software program. 
All collected data were processed and statistically analyzed and comparison of bone height changes was done between the two groups of the study.

(LO) line joining the inferior points of the borders of the bony orbits. (LZ) line was drawn joining the inferior margins of the images of the zygomatic processes of the maxillae. (x) line joining most inferior points of borders of bony orbits to line joining inferior margins of images of zygomatic processes. (y) line from zygomatic processes line to alveolar crest. (z) line from zygomatic processes line to alveolar crest from a point representing the middle of abc (a) point of intersection of the most inferior point of the orbit with LZ line. (b) point of intersection of midline with LZ line. (c) point of intersection of the most inferior point of the orbit with LO line.

(LO) line joining the inferior points of the borders of the bony orbits. (LZ) line was drawn joining the inferior margins of the images of the zygomatic processes of the maxillae. (x) Line joining most inferior points of borders of bony orbits to line joining inferior margins of images of zygomatic processes. $\mathrm{X} 1=48.9 \mathrm{~mm}$ (Rt. Side), X2=47.9mm (Lt. side) (y) Line from zygomatic processes line to alveolar crest.Y1=27.8mm (Rt. Side), Y2=24.1mm (Lt. side) (z) Line from zygomatic processes line to alveolar crest from a point representing the middle of abc. Z1=37.8mm (Rt. Side), Z2=33.6mm (Lt. Side).

\section{Statistical Analysis}

Statistical analysis was performed using "SPSS" (statistical software release 12 for windows). A probability level (P-value) $\leq 0.05$ was considered statistically significant, less than 0.01 was considered highly significant. Descriptive data were summarized as means, standard deviations. Paired t-test was used for testing the effect of time on maxillary tissue changes throughout the different time intervals of the study period for each group, and independent t-test was used to compare between the two groups during the time intervals of the study period.

\section{RESULTS}

\section{I- Clinical Evaluation Results}

Mean changes of soft tissue thickness overlying maxillary anterior ridge $(1 \mathrm{~cm}$ and $2 \mathrm{cmm}$ to midline) in Group I and II are presented in table (1). Within both groups, the means of soft tissue thickness overlying maxillary anterior ridge were generally increasing than that at the time of insertion during follow up at both points ( $1 \mathrm{~cm}$ and $2 \mathrm{~cm}$ to midline). Those changes were statistically non-significant.

The comparison of soft tissue thickness mean values overlying maxillary anterior ridge $(1 \mathrm{~cm}$ and $2 \mathrm{~cm}$ to midline) is presented in table (2) shows at time of denture implant loading, three, six, nine and twelve months after implant loading between Group I and Group II. The means of changes in soft tissue thickness overlying maxillary anterior ridge $(1 \mathrm{~cm}$ and $2 \mathrm{~cm}$ to midline) for Group II; were generally higher than that for Group I through follow up period. However, those differences were statistically non-significant.

\section{II-Results of Radiographic Evaluation:}

Posterior radiographic bony changes in maxillary ridge $(\mathrm{X} / \mathrm{Y})$ within Group I and Group II are presented in table (3). The means of radiographic evaluation $(\mathrm{X} / \mathrm{Y}$ ratio) and $(\mathrm{X} / \mathrm{Z}$ ratio) increased throughout follow up period within Group I and within Group II. Those differences were statistically significant at 6,9 and 12 months.

Comparison of posterior radiographic bony changes in maxillary ridge between Group I and Group II regarding $(\mathrm{X} / \mathrm{Y})$ and $(\mathrm{X} / \mathrm{Z})$ values is presented in table (4). The $(\mathrm{X} / \mathrm{Y})$ values were higher in Group II than Group I. These differences were significant at 6,9 and 12 months. However, the $(\mathrm{X} / \mathrm{Z})$ values were non-significant although values were higher in Group II than Group I throughout follow up period. 
Table (1): Mean changes of soft tissue thickness overlying maxillary anterior ridge $(1 \mathrm{~cm}$ and $2 \mathrm{~cm}$ to midline) within Group I and II during follow up period.

\begin{tabular}{|c|c|c|c|c|c|c|}
\hline \multirow{18}{*}{ 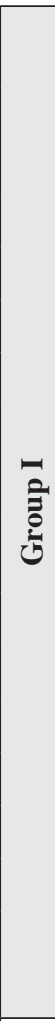 } & $\begin{array}{l}\text { Soft tissue thickness overlying maxillary } \\
\text { anterior ridge ( } 1 \mathrm{~cm} \text { to midline) }\end{array}$ & Mean & SD & $\mathbf{T}$ & P-value & Sig. \\
\hline & At implant loading & 1.57 & 0.2 & \multirow{2}{*}{-5.67} & \multirow{2}{*}{0.1} & \multirow{2}{*}{ NS } \\
\hline & Three months & 1.64 & 0.3 & & & \\
\hline & At implant loading & 1.57 & 0.2 & \multirow{2}{*}{-5.67} & \multirow{2}{*}{0.1} & \multirow{2}{*}{ NS } \\
\hline & Six months & 1.64 & 0.3 & & & \\
\hline & At implant loading & 1.57 & 0.2 & \multirow{2}{*}{-9.0} & \multirow{2}{*}{0.0 .7} & \multirow{2}{*}{ NS } \\
\hline & Nine months & 1.65 & 0.3 & & & \\
\hline & At implant loading & 1.57 & 0.2 & \multirow{2}{*}{-9.0} & \multirow{2}{*}{0.07} & \multirow{2}{*}{ NS } \\
\hline & Twelve months & 1.82 & 0.4 & & & \\
\hline & $\begin{array}{l}\text { Soft tissue thickness overlying maxillary } \\
\text { anterior ridge ( } 2 \mathrm{~cm} \text { to midline) }\end{array}$ & Mean & SD & $\mathbf{T}$ & P-value & Sig. \\
\hline & At implant loading & 1.50 & 0.3 & \multirow{2}{*}{-6.0} & \multirow{2}{*}{0.1} & \multirow{2}{*}{ NS } \\
\hline & Three months & 1.64 & 0.4 & & & \\
\hline & At implant loading & 1.50 & 0.3 & \multirow{2}{*}{-6.0} & \multirow{2}{*}{0.1} & \multirow{2}{*}{ NS } \\
\hline & Six months & 1.64 & 0.4 & & & \\
\hline & At implant loading & 1.50 & 0.3 & \multirow{2}{*}{-5.0} & \multirow{2}{*}{0.1} & \multirow{2}{*}{ NS } \\
\hline & Nine months & 1.65 & 0.4 & & & \\
\hline & At implant loading & 1.50 & 0.3 & \multirow{2}{*}{-3.5} & \multirow{2}{*}{0.2} & \multirow{2}{*}{$\mathrm{NS}$} \\
\hline & Twelve months & 1.68 & 0.4 & & & \\
\hline \multirow{18}{*}{ 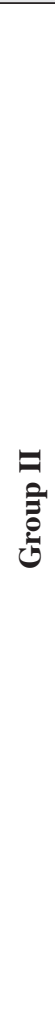 } & $\begin{array}{l}\text { Soft tissue thickness overlying maxillary } \\
\text { anterior ridge }(1 \mathrm{~cm} \text { to midline) }\end{array}$ & Mean & SD & $\mathbf{T}$ & P-value & Sig. \\
\hline & At implant loading & 2.43 & 0.2 & 567 & 01 & NS \\
\hline & Three months & 2.50 & 0.3 & -3.01 & 0.1 & NS \\
\hline & At implant loading & 2.43 & 0.2 & & & \\
\hline & Six months & 2.55 & 0.3 & -11.0 & 0.06 & NS \\
\hline & At implant loading & 2.43 & 0.2 & -110 & 006 & NS \\
\hline & Nine months & 2.55 & 0.3 & -11.0 & 0.00 & IVS \\
\hline & At implant loading & 2.43 & 0.2 & 00 & 007 & NS \\
\hline & Twelve months & 2.68 & 0.4 & -9.0 & 0.07 & NS \\
\hline & $\begin{array}{l}\text { Soft tissue thickness overlying maxillary } \\
\text { anterior ridge ( } 2 \mathrm{~cm} \text { to midline) }\end{array}$ & Mean & SD & $\mathbf{T}$ & P-value & Sig. \\
\hline & At implant loading & 2.57 & 0.2 & -567 & & \\
\hline & Three months & 2.64 & 0.3 & $-5.6 /$ & 0.1 & NS \\
\hline & At implant loading & 2.57 & 0.2 & 60 & 01 & NS \\
\hline & Six months & 2.71 & 0.3 & -0.0 & 0.1 & INS \\
\hline & At implant loading & 2.57 & 0.2 & & & \\
\hline & Nine months & 2.75 & 0.3 & -3.5 & 0.2 & NS \\
\hline & At implant loading & 2.57 & 0.2 & -233 & 03 & NS \\
\hline & Twelve months & 2.82 & 0.3 & -2.53 & 0.3 & INS \\
\hline
\end{tabular}

SD: standard deviation, $P$-value $=$ Probability level for the effect of time $($ Paired T test $), N S=$ non-significant at $P>0.05$ 
Table (2): Comparison between Group I and II regarding changes in soft tissue thickness overlying maxillary anterior ridge ( $1 \mathrm{~cm}$ and $2 \mathrm{~cm}$ to midline).

\begin{tabular}{|c|c|c|c|c|c|c|c|}
\hline & & & Mean & SD & $\mathrm{T}$ & P-value & Sig. \\
\hline \multirow{8}{*}{$\begin{array}{l}\text { Changes in soft tissue thickness } \\
\text { overlying maxillary anterior } \\
\text { ridge ( } 1 \mathrm{~cm} \text { to midline) }\end{array}$} & \multirow{2}{*}{$\begin{array}{l}\text { Implant loading } \\
\text { - till three months }\end{array}$} & Group I & 0.07 & 0.1 & \multirow{2}{*}{0.000} & \multirow{2}{*}{1.0} & \multirow{2}{*}{ NS } \\
\hline & & Group II & 0.07 & 0.1 & & & \\
\hline & \multirow{2}{*}{$\begin{array}{l}\text { Implant loading } \\
\text { - till six months }\end{array}$} & Group I & 0.07 & 0.1 & \multirow{2}{*}{-0.94} & \multirow{2}{*}{0.4} & \multirow{2}{*}{ NS } \\
\hline & & Group II & 0.12 & 0.1 & & & \\
\hline & \multirow{2}{*}{$\begin{array}{l}\text { Implant loading } \\
\text { - till nine months }\end{array}$} & Group I & 0.08 & 0.1 & \multirow{2}{*}{-0.75} & \multirow{2}{*}{0.5} & \multirow{2}{*}{ NS } \\
\hline & & Group II & 0.12 & 0.1 & & & \\
\hline & \multirow{2}{*}{$\begin{array}{l}\text { Implant loading } \\
\text { - till twelve months }\end{array}$} & Group I & 0.25 & 0.2 & \multirow{2}{*}{0.000} & \multirow{2}{*}{1.0} & \multirow{2}{*}{ NS } \\
\hline & & Group II & 0.25 & 0.2 & & & \\
\hline \multirow{8}{*}{$\begin{array}{l}\text { Changes in soft tissue thickness } \\
\text { overlying maxillary anterior } \\
\text { ridge }(2 \mathrm{~cm} \text { to midline })\end{array}$} & \multirow{2}{*}{$\begin{array}{l}\text { Implant loading } \\
\text { - till three months }\end{array}$} & Group I & 0.14 & 0.1 & \multirow{2}{*}{1.30} & \multirow{2}{*}{0.2} & \multirow{2}{*}{ NS } \\
\hline & & Group II & 0.07 & 0.1 & & & \\
\hline & \multirow{2}{*}{$\begin{array}{l}\text { Implant loading- till } \\
\text { six months }\end{array}$} & Group I & 0.14 & 0.1 & \multirow{2}{*}{0.00} & \multirow{2}{*}{1.0} & \multirow{2}{*}{ NS } \\
\hline & & Group II & 0.14 & 0.1 & & & \\
\hline & \multirow{2}{*}{$\begin{array}{l}\text { Implant loading - till } \\
\text { nine months }\end{array}$} & Group I & 0.15 & 0.1 & \multirow{2}{*}{-0.56} & \multirow{2}{*}{0.6} & \multirow{2}{*}{ NS } \\
\hline & & Group II & 0.18 & 0.1 & & & \\
\hline & \multirow{2}{*}{$\begin{array}{l}\text { Implant loading - till } \\
\text { twelve months }\end{array}$} & Group I & 0.18 & 0.1 & \multirow{2}{*}{-1.31} & \multirow{2}{*}{0.2} & \multirow{2}{*}{ NS } \\
\hline & & Group II & 0.25 & 0.1 & & & \\
\hline
\end{tabular}

Table (3): Mean changes of radiographic evaluation values (X/Y ratio) and (X/Z ratio) within Group I and Group II during follow up period.

\begin{tabular}{|c|c|c|c|c|c|c|}
\hline & $\mathbf{X} / \mathbf{Y}$ & Mean & SD & $\mathbf{T}$ & P-value & Sig. \\
\hline \multirow{17}{*}{$\frac{0}{5}$} & At implant loading & 1.73 & 0.5 & \multirow{2}{*}{-4.0} & \multirow{2}{*}{0.2} & \multirow{2}{*}{ NS } \\
\hline & Three months & 1.79 & 0.6 & & & \\
\hline & At implant loading & 1.73 & 0.5 & \multirow{2}{*}{-3.42} & \multirow{2}{*}{0.01} & \multirow{2}{*}{$\mathrm{S}$} \\
\hline & Six months & 2.30 & 0.9 & & & \\
\hline & At implant loading & 1.73 & 0.5 & \multirow{2}{*}{-4.50} & \multirow{2}{*}{0.004} & \multirow{2}{*}{ HS } \\
\hline & Nine months & 2.59 & 1.0 & & & \\
\hline & At implant loading & 1.73 & 0.5 & \multirow{2}{*}{-4.23} & \multirow{2}{*}{0.006} & \multirow{2}{*}{ HS } \\
\hline & Twelve months & 2.90 & 1.2 & & & \\
\hline & $\mathbf{X} / \mathbf{Z}$ & Mean & SD & $\mathbf{t}$ & P-value & Sig. \\
\hline & At implant loading & 1.30 & 0.4 & \multirow{2}{*}{-2.33} & \multirow{2}{*}{0.3} & \multirow{2}{*}{ NS } \\
\hline & Three months & 1.34 & 0.5 & & & \\
\hline & At implant loading & 1.30 & 0.4 & \multirow{2}{*}{-4.40} & \multirow{2}{*}{0.005} & \multirow{2}{*}{ HS } \\
\hline & Six months & 1.71 & 0.5 & & & \\
\hline & At implant loading & 1.30 & 0.4 & \multirow{2}{*}{-3.70} & \multirow{2}{*}{0.01} & \multirow{2}{*}{$\mathrm{S}$} \\
\hline & Nine months & 1.95 & 0.6 & & & \\
\hline & At implant loading & 1.30 & 0.4 & \multirow{2}{*}{-3.68} & \multirow{2}{*}{0.01} & \multirow{2}{*}{ S } \\
\hline & Twelve months & 2.13 & 0.7 & & & \\
\hline
\end{tabular}




\begin{tabular}{|c|c|c|c|c|c|c|}
\hline \multirow{18}{*}{$\frac{0}{5}$} & $\mathrm{X} / \mathrm{Y}$ & Mean & SD & $\mathbf{T}$ & P-value & Sig. \\
\hline & At implant loading & 3.42 & 1.9 & \multirow{2}{*}{-1.22} & \multirow{2}{*}{0.3} & \multirow{2}{*}{ NS } \\
\hline & Three months & 3.53 & 2.0 & & & \\
\hline & At implant loading & 3.42 & 1.9 & \multirow{2}{*}{-3.27} & \multirow{2}{*}{0.02} & \multirow{2}{*}{$\mathrm{S}$} \\
\hline & Six months & 5.78 & 3.8 & & & \\
\hline & At implant loading & 3.42 & 1.9 & \multirow{2}{*}{-3.38} & \multirow{2}{*}{0.02} & \multirow{2}{*}{$\mathrm{S}$} \\
\hline & Nine months & 7.21 & 4.9 & & & \\
\hline & At implant loading & 3.42 & 1.9 & \multirow{2}{*}{-3.09} & \multirow{2}{*}{0.02} & \multirow{2}{*}{ S } \\
\hline & Twelve months & 8.93 & 6.6 & & & \\
\hline & $\mathrm{X} / \mathrm{Z}$ & Mean & SD & $\mathbf{T}$ & P-value & Sig. \\
\hline & At implant loading & 2.31 & 0.9 & \multirow{2}{*}{-2.07} & \multirow{2}{*}{0.08} & \multirow{2}{*}{ NS } \\
\hline & Three months & 2.34 & 1.0 & & & \\
\hline & At implant loading & 2.31 & 0.9 & \multirow{2}{*}{-2.74} & \multirow{2}{*}{0.03} & \multirow{2}{*}{$\mathrm{S}$} \\
\hline & Six months & 3.87 & 2.4 & & & \\
\hline & At implant loading & 2.31 & 0.9 & \multirow{2}{*}{-2.56} & \multirow{2}{*}{0.04} & \multirow{2}{*}{$\mathrm{S}$} \\
\hline & Nine months & 5.41 & 4.0 & & & \\
\hline & At implant loading & 2.31 & 0.9 & \multirow{2}{*}{-6.365} & \multirow{2}{*}{0.001} & \multirow{2}{*}{ HS } \\
\hline & Twelve months & 5.50 & 4.1 & & & \\
\hline
\end{tabular}

NS = not significant $P>0.05, \quad S=$ significantly difference $P<0.05, \quad H S=$ significantly difference $P<0.01$

Table (4): Comparison between Group I and II regarding changes in radiographic evaluation values (X/Y ratio) and (X/Z ratio).

\begin{tabular}{|c|c|c|c|c|c|c|c|}
\hline \multirow{9}{*}{ 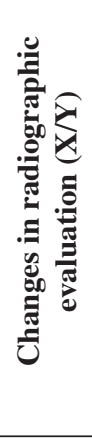 } & & & Mean & SD & $\mathbf{t}$ & P-value & Sig. \\
\hline & \multirow{2}{*}{ Implant loading- till three months } & Group I & 0.06 & 0.1 & \multirow{2}{*}{-0.94} & \multirow{2}{*}{0.4} & \multirow{2}{*}{ NS } \\
\hline & & Group II & 0.11 & 0.1 & & & \\
\hline & \multirow{2}{*}{ Implant loading- till six months } & Group I & 0.57 & 0.4 & \multirow{2}{*}{-2.44} & \multirow{2}{*}{0.03} & \multirow{2}{*}{$\mathrm{S}$} \\
\hline & & Group II & 2.36 & 1.9 & & & \\
\hline & \multirow{2}{*}{ Implant loading - till nine months } & Group I & 0.86 & 0.5 & \multirow{2}{*}{-2.55} & \multirow{2}{*}{0.03} & \multirow{2}{*}{$\mathrm{S}$} \\
\hline & & Group II & 3.79 & 3.0 & & & \\
\hline & \multirow{2}{*}{$\begin{array}{c}\text { Implant loading - till twelve } \\
\text { months }\end{array}$} & Group I & 1.17 & 0.7 & \multirow{2}{*}{-2.42} & \multirow{2}{*}{0.03} & \multirow{2}{*}{$\mathrm{S}$} \\
\hline & & Group II & 5.51 & 4.7 & & & \\
\hline \multirow{9}{*}{ 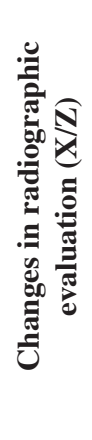 } & & & Mean & SD & $\mathbf{t}$ & P-value & Sig. \\
\hline & \multirow{2}{*}{ Implant loading - till three months } & Group I & 0.04 & 0.1 & \multirow{2}{*}{0.19} & \multirow{2}{*}{0.9} & \multirow{2}{*}{ NS } \\
\hline & & Group II & 0.03 & 0.1 & & & \\
\hline & \multirow{2}{*}{ Implant loading- till six months } & Group I & 0.41 & 0.1 & \multirow{2}{*}{-2.02} & \multirow{2}{*}{0.07} & \multirow{2}{*}{ NS } \\
\hline & & Group II & 1.56 & 1.5 & & & \\
\hline & \multirow{2}{*}{ Implant loading - till nine months } & Group I & 0.65 & 0.2 & \multirow{2}{*}{-2.09} & \multirow{2}{*}{0.06} & \multirow{2}{*}{ NS } \\
\hline & & Group II & 3.1 & 3.1 & & & \\
\hline & \multirow{2}{*}{$\begin{array}{c}\text { Implant loading - till twelve } \\
\text { months }\end{array}$} & Group I & 0.83 & 0.3 & \multirow{2}{*}{-1.94} & \multirow{2}{*}{0.08} & \multirow{2}{*}{ NS } \\
\hline & & Group II & 3.19 & 3.2 & & & \\
\hline
\end{tabular}

$N S=$ not significant $P>0.05 \quad S$ significantly difference $P<0.05$ 


\section{DISCUSSION}

A mandibular implant supported overdenture is an excellent treatment option for fully edentulous patients in terms of masticatory function, chewing ability and patient's satisfaction. To improve support and stability of a denture, various numbers of implants have been recommended for mandibular implant overdentures ${ }^{(17,18)}$.

Flapless implant surgery was used as it is becoming an alternative protocol for conventional flap surgery for dental implant placement due to its advantages which includes less traumatic surgery, decreased operative time, rapid post-surgical healing, fewer post-operative complications, increased patient comfort ${ }^{(19,20)}$.

The minimum number of implants required for adequate anchorage of a complete denture varies according to the prosthetic concept used ${ }^{(17,18)}$. The use of two inter-foraminal implants installed in the inter-foraminal area has proved to be very successful in stabilizing and retaining an overdenture as well as it is the most favorable for implant position in terms of bone stresses and part of mastication force transiting through mucosa ${ }^{(21)}$. While other authors found that placement of single implant in the symphyseal region enhance stability and function more than complete denture because of favorable local bone quality and quantity ${ }^{(7,13)}$. In addition, mandibular midline region had a dense osseous and very near from the lingual foramen (that cross the mandible at the midline from the lingual to the buccal), so the osteotomy was shifted $1 \mathrm{~mm}$ to avoid its injury ${ }^{(22)}$. Also, some authors found that the mandibular midline region is the safest region of the mandible with no difficulty in implant insertion and it has a great advantage in patients with a compromised atrophic mandible opposing a maxillary complete denture ${ }^{(21,23-25)}$.

Ball and socket attachments were used, because they permit some rotation and vertical resilience and allow multidirectional free movement of the prosthesis, so acting as a shock absorber decreasing load on the abutments thus relieving the fixtures from unfavorable forces $(9,26,27)$.

As the mucosally supported mandibular overdenture was opposed by completely edentulous maxilla, a bilateral balanced scheme with no anterior contact in centric occlusion and minimal contact in lateral or protrusive movement has been recommended and established balanced occlusion which improves the load distribution, reduces component failure and does not potentiate parafunctional activity which has been suggested to lead to an increase in bone loss around implants. ${ }^{(28,29)}$

In this study the maxilla was the area of study to show the effect different designs of mandibular implant supported overdenture on antagonist maxillary soft tissue and bone height changes ${ }^{(30-32,34)}$.

The result of the present study showed a slight increase in the thickness of mucosa in the anterior region in both groups during follow up period. (Group I with mainly mucosa implant supported mandibular overdenture on two implants and Group II with mucosa implant supported mandibular overdenture on single midline implants), but this increase was non-significant ${ }^{(14)}$. While, by comparing the changes of soft tissues thickness between both groups, there was slight increase in soft tissue thickness in Group II more than Group I but this difference was statistically non-significant.

The result of this study showed also that the decrease in radiographic bone height was always more in the posterior region than in the anterior region of maxillary jaw bone in both groups. This is in contrast with a study (26) that was reported pronounced resorption in the anterior maxilla which is similar to symptoms of combination syndrome described by Kelly which was explained to loss in the posterior occlusal contacts ${ }^{(5,11)}$. 
By comparing maxillary bone height changes in both groups of this study, it was found that the posterior bone height changes was more in Group II patients with single sympheseal implant mucosa supported overdentures than Group I patients with two implant-mucosa supported mandibular overdenture and these differences were statistically significant. This could be explained by loss of posterior support in patients of Group II and instability of the complete dentures, which contributes to an unfavorable stress distribution among the denture bearing areas which was in agreement with another study ${ }^{(33)}$, that found more pronounced maxillary bone resorption in patients with complete mandibular denture compared to patients with two implant-mucosa supported mandibular overdentures. This also agrees with several studies ${ }^{(34-36)}$ that found improved tissue health and reduced annual residual ridge resorption in supporting tissues of prostheses that oppose a mandibular implant overdenture.

Although in the present study found the anterior maxillary bone height changes was more in Group II than Group I but this differences were statistically non-significant. This result agrees with another study that could not demonstrate a correlation between the occurrence of morphological changes of anterior maxillary bone and different implant overdentures in the opposing arch. The changes occurred in the jaw after 6 years was investigated after the treatment with conventional maxillary denture and various types of mandibular implant prosthesis. Following the clinical observations and measurements made, the maxillary resorption was considered low and not related to the prosthetic mandibulary modality of treatment ${ }^{(37)}$.

Due to the relatively small number of articles investigating this issue, more studies are needed to provide additional data about the influence of different mandibular implant supported overdentures on edentulous maxillary tissue changes and consequently on its conventional denture ${ }^{23,37)}$.

\section{CONCLUSION}

Within the limitations of this study, it was concluded that:

There was slight increase in the soft tissue thickness overlying the anterior maxillary ridge in each group. But there was slight increase in Group II (patients received mandibular overdenture retained with single implant in the midline with ball and socket attachment) more than Group I (patients received mandibular overdenture retained with 2 implants in the canine region bilaterally with ball and socket attachment). Also, a more pronounced bone resorption in posterior region of maxilla was observed in Group II patients.

\section{RECOMMENDATIONS}

Due to the relatively small number of articles investigating this issue, more and long term follow up studies are needed to provide additional data about the effect of different designs of mandibular implant supported overdentures on edentulous maxillary ridge tissues under maxillary complete denture.

\section{REFERENCES}

1. Al-sabeeha N, Payne A, De Silva R and Swain M: Mandibular single-implant overdentures: a review with surgical and prosthodontic perspectives of a novel approach. Clin Oral Implants Res 2009; 4:356-65.

2. Kawai $\mathrm{Y}$ and Taylor J: Effect of loading time on the success of complete mandibular titanium implant retained overdentures: a systematic review. Clin Oral Impl Res 2007; 18:399-08.

3. Attard NJ, Zarb GA. Long-term treatment outcomes in edentulous patients with implant overdentures: the Toronto study. Int J Prosthodont 2004; 17: 417-24.

4. Naert I, Alsaadi G, Van Steenberghe D and Quirynen M: A 10 years randomized clinical trial on the influence of splinted and unsplinted oral implants retaining mandibular overdentures: Peri-implant outcome. Int J Oral Maxillofac Implants 2004; 19:695-02.

5. Kelly E: Changes caused by a mandibular removable partial denture opposing a maxillary complete denture. J Prosth Dent 2003; 90:213-19. 
6. Saglam A: The vertical heights of maxillary and mandibular bones in panoramic radiographs of dentate and edentulous subjects. Quintes Intern 2002; 33:433-38.

7. Lechner S and Mammen A: Combination syndrome in relation to osseointegrated implant-supported overdentures: A survey. Int J Prosthod 1996; 9: 58-64.

8. Wright P, Glantz P, Randow K and Watson R: The effects of fixed and removable implant-stabilized prostheses on posterior mandibular residual ridge resorption. Clin Oral Impl Res 2002; 13:169-74.

9. Tallergen A: The continuing reduction of the residual alveolar ridges in complete denture wearers. A mixed longitudinal study covering 25 years. J Prosthet Dent 2003; 89:427-35.

10. Bakke M, Holm B and Gotfredsen K: Masticatory function and patient satisfaction with implant-supported mandibular overdenture: a prospective 5-year study. Int J Prosthod 2002; 5:575-81.

11. Kelly E: Changes caused by a mandibular removable partial denture opposing a maxillary complete denture. J Prosth Dent 1972; 27:140-50.

12. Carlsson G: Measurements on Casts of the Edentulous Maxilla. Odont Revy 1966; 17:386-02.

13. Maeda $Y$, Horisaka $M$ and Yagi K: Biomechanical rationale for a single implant-retained mandibular overdenture: an in vitro study. Clin Oral Impl Res 2008; 19:271-75.

14. Mohie-Eldin H, Lebshtien I and Mady Y: Evaluation of maxillary bone resorption and the development of combination syndrome in mandibular bilateral distal extension cases opposed by a maxillary overdenture. Egyp Dent J 2000; 46:273.

15. Jonas P, Becktor D, Steven E, Eckert O, StenIsaksson P, Eugene E and Keller L: The Influence of Mandibular Dentition on Implant failures in Bone-grafted Edentulous Maxillae. Int J Oral Maxillofac Implants 2002; 17:69-77.

16. De Kok I, Chang K, Lu T and Cooper L: Comparison of three-implant-supported fixed dentures and two-implantretained overdentures in the edentulous mandible: a pilot study of treatment efficacy and patient satisfaction. Int $\mathrm{J}$ Oral Maxillofac Implants 2011; 26:415-26.

17. Kronstrom M, Davis B, Loney R, Gerrow J, Hollender L. A prospective randomized study on the immediate loading of mandibular overdentures supported by one or two implants: a 3 year follow-up report. Clin Implant Dent Relat Res 2014;16:323-9.
18. El-Sheikh AM, Shihabuddin OF, Ghoraba SM. Two versus three narrow-diameter implants with locator attachments supporting mandibular overdentures: a twoyear prospective study. Int J Dent 2012;2012:285684.

19. Torresanto VM, Milinkovic I, Torsello F, Cordaro L. Computer-assisted flapless implant surgery in edentulous elderly patients: a 2-year follow up. Quintessence Int 2014; 45:419-29.

20. Nocini PF, Castellani R, Zanotti G, Bertossi D, Luciano U, De Santis D. The use of computer-guided flapless dental implant surgery (NobelGuide) and immediate function to support a fixed full-archprosthesis infresh-frozen homologous patients with bone grafts. J Craniofac Surg 2013;24:e551-8.

21. Rosano G, TaschieriS,Franc $\mathrm{J}_{3}$ Gaudy O, Testori T and Del Fabbro M: Anatomic assessment of the anterior mandible and relative hemorrhage risk in implant dentistry: a cadaveric study. John Wiley \& Sons. Clin Oral Impl Res 2009; 20:791-95.

22. Agur A: Grant's Atlas of Anatomy. 9th ed Baltimore, Williams and Wilkins 1991; p. 501.

23. Krennmair $\mathrm{G}$ and Ulm $\mathrm{C}$ : The symphyseal single-tooth implant for anchorage of a mandibular complete denture in geriatric patients: a clinical report. Int J Oral Maxillofac Implants 2001; 16:98-104.

24. Alsabeeha N, Payne A, De Silva R and Thomson W: Mandibular single-implant overdentures: preliminary results of a randomised-control trial on early loading with different implant diameters and attachment systems.Clin Oral Implants Res 2011; 22:330-37.

25. Cheng T, Ma Li, Liu XL, Sun GF, He XJ, Huo JY, Wang YN. Use of a single implant to retain mandibular overdenture: A preliminary clinical trial of 13 cases J Dent Sci 2012; 7: 261-266

26. Savabi O, Nejatidanesh $\mathrm{F}$ and Yordshahian F: Retention of implant-supported overdenture with bar/clip and stud attachment designs. J Oral Implantol 2011; 9: 1563-64.

27. Jacobs R, Schotte A, van Steenberghe D, Quirynen M and Naert I: Posterior jaw bone resorption in osseointegrated implant-supported overdentures. Clin Oral Impl Res 1992; 3:63-70.

28. Magdy H, El Afandy M and Ead M: The effect of occlusal design on muscle activity in implant supported mandibular overdentures. Cairo Dent J 2008; 24:335-50. 
29. Ural C, Bereket C, Şener İ, Murat A and Ziya Y: Bone height measurement of maxillary and mandibular bones in panoramic radiographs of edentulous patients. J Clin Exp Dent 2011; 3: 5-9.

30. Brewer A and Morrow R: Overdentures.2nd edition C.V. Mosby Co., St. Louis, London, 1980; (34-66), (208-52).

31. Kreisler M, Behneke N, Behneke A and Hoedt B: Residual Ridge resorption in the edentulous maxilla in patients with implant- supported mandibular overdentures: an 8-year retrospective study. Int J Prosth 2003; 16: 295-00.

32. Masri R: Clinical manual of implant dentistry. J Prosthodont 2003; 12: 334-35.

33. Jacobs R, van Steenberghe D, Nys M and Naert I: Maxillary bone resorption in patients with mandibular implant-supported overdentures or fixed prostheses.J Prosthet Dent 1993; 70:135-40.

34. Nelson K, Heberer S and Glatzer C: Survival analysis and clinical evaluation of implant retained prosthesis in oral cancer resection patients over a mean follow-up period of 10 years. J Prosthet Dent 2007; 98:406-10.

35. Burns D: The mandibular complete overdenture. Dent Clin NA 2004; 48:603-23.

36. Tuncay O, Thomson S, Abadi $\mathrm{B}$ and Ellinger C: Cephalometric evaluation of the changes in patients wearing complete dentures. A ten-year longitudinal study. J Prosthet Dent 1984; 51:169-80.

37. Närhi T, Geertman E, Hevinga M, Abdo H and Kalk W: Changes in the edentulous maxilla in persons wearing implant-retained mandibular overdentures. J Prosthet Dent 2000; 84:43-49. 